\title{
PEMBERDAYAAN MASYARAKAT RW 12 DALAM KEGIATAN PENGHIJAUAN LINGKUNGAN DI KAVLING MANDIRI KELURAHAN SEI PELUNGGUT
}

\section{COMMUNITY EMPOWERMENT OF RW 12 IN ENVIRONMENTAL ACTIVITY AT KAVLING MANDIRI OF KELURAHAN SEI PELUNGUT}

\author{
Diah Ayu Pratiwi ${ }^{1}$ \\ ${ }^{I}$ Ilmu Pemerintahan, Fakultas Ilmu Sosial dan Ilmu Politik, Universitas Riau Kepualuan
}

\begin{abstract}
Abstrak
Kavling Mandiri (Kelurahan Sei Pelunggut) merupakan wilayah yang terletak di Kecamatan Sagulung, Kota Batam. Lingkungan di wilayah ini sangat gersang dan sering mengalami banjir setiap turun hujan. Daya serap air yang kurang dan drainase yang buruk menjadi penyebab muncul banjir di wilayah tersebut. Selain itu, juga dikarenakan kurangnya kesadaran dan perhatian warga terhadap lingkungan. Hal ini disebabkan kesibukan warga RW12 yang bekerja dalam memenuhi kebutuhan sehari-hari. Mayoritas tingkat pendidikan warga RW 12 adalah lulusan SLTA. Meski demikian, saat ini sudah banyak warga RW12 yang mengenyam pendidikan sarjana namun peran terhadap lingkungan masih rendah.

Tujuan dari pengabdian ini meningkatkan kesadaran masyarakat RW 12 mengenai pentingnya melakukan kegiatan penghijauan lingkungan guna menjaga kualitas lingkungan dan perindangan di lingkungan RW 12. Metode kegiatan ini dilakukan dengan menggunakan pendekatan persuasif, pendekatan emiprik, normatik dan edukatif, dan pendekatan androgogi dengan tujuan meningkat partisipasi masyarakat RW 12 dalam kegiatan penghijauan lingkungan. Kegiatan penghijauan dilakukan melalui penanaman pohon dan memberikan pengetahuan serta pemahaman kepada masyarakat mengenai pentingnya melestarikan lingkungan.

Dengan peningkatan daya serap air dan mendukung kegiatan yang dapat meningkatkan kualitas lingkungan di RW 12 maka dapat mencegah terjadinya banjir serta menjadikan lingkungan tersebut asri dan rindang..
\end{abstract}

Kata Kunci: pemberdayaan masyarakat, penghijuan lingkungan, pendekatan persuasif

\begin{abstract}
Kavling Mandiri (Kelurahan Sei Pelunggut) is an area located in Sagulung District, Batam City. The environment in this region is very arid and often experiences flooding every rainy day. Lack of water absorption and poor drainage are the cause of flooding in the area. In addition, due to lack of awareness and attention of citizens to the environment. This is due to the busyness of RW12 residents who work in meeting their daily needs. The majority of the education level of RW 12 are high school graduates. However, currently many RW12 residents have undergraduate education but their role for the environment is still low.

The purpose of this dedication is to arise awareness of $R W 12$ resident about environmental concerns in $R W 12$. The method of this activity is done by using persuasive approach, empiric approach, normative and educative, and andragogy approach to increase the participation resident of RW12 for environmental activities. The activities are made through tree planting and provide knowledge and understanding to the resident about the importance of preserving the environment.

By increasing the water absorption and support activities that can improve the environmental quality in RW 12 it can prevent the occurrence of floods and make the environment is beautiful and shady.
\end{abstract}

Keywords: empowerment community, environmental activities, persuasive approach 


\section{PENDAHULUAN}

Pelestarian lingkungan melalui kegiatan penghijauan telah berkembang di Indonesia sebagai upaya dalam penyelamatan lingkungan. Indonesia merupakan salah satu Negara yang memiliki kepadatan penduduk terbesar di dunia, memungkinkan adanya masalah lingkungan yang ditimbulkan akibat dari ulah manusia. Semakin meningkatnya jumlah penduduk akan menimbulkan berbagai permasalahan sendiri mulai dari masing-masing individu sampai dengan industri besar yang menghasilkan limbah industri.

Kepadatan penduduk meningkat terutama di wilayah perkotaan. Kota menjadi daya tarik tersendiri bagi masyarakat, karena di kota berbagai kebutuhan mulai dari pelayanan kesehatan, pendidikan, pekerjaan yang menjanjikan, serta pertumbuhan ekonomi yang stabil tersedia di kota. Jumlah penduduk di kota cenderung mengalami peningkatan setiap tahunnya seiring arus urbanisasi yang tinggi. Padatnya jumlah penduduk berpengaruh terhadap kerusakan lingkungan yang diakibatkan oleh ulah manusia sendiri, seperti buang sampah sembarangan, sanitasi dan drainase yang buruk, serta munculnya pemukiman kumuh. Hal ini tidak terlepas dari rendahnya pengetahuan, pendidikan yang terbatas, serta pemenuhan kebutuhan sehari-hari yang kurang memadai membuat masyarakat miskin utamanya hanya berusaha menpertahankan hidup tanpa terlintas untuk menjaga lingkungan. Apalagi, pembangunan industri yang semakin pesat di kota menambah beban bagi lingkungan dalam hal polusi dan limbah industri.

Dalam mengatasi permasalahan lingkungan diperkotaan, beberapa kota di Indonesia telah mengembangkan program yang ramah terhadap lingkungan sebagai upaya menjaga keberlanjutan lingkungan. Berbagai aksi yang dilakukan oleh masyarakat dalam mengatasi permasalahan lingkungan yang dimulai dari skala individu. Berbagai aksi seperti penanaman pohon rindang, tata cara berkebun dalam lahan sempit, dan mengembangkan program kampong hijau sebagai kampanye menjaga kebersihan dan penghijauan lingkungan di kampungkampung yang padat penduduk.

Kota Batam merupakan salah satu kota dengan jumlah penduduk yang padat di Kepulauan Riau. Secara geografis, Kota Batam memiliki posisi yang strategis berbatasan langsung dengan Singapura dan Malaysia, sehingga menjadikan Kota Batam sebagai salah satu 
pusat perekonomian di Propinsi kepulauan Riau dan menjadi kawasan industri terbesar di Indonesia. Sebagai daerah industri, Kota Batam menarik minat para pendatang untuk mengadu nasib.

Penduduk Kota Batam mengalami pertumbuhan penduduk yang cukup tinggi. Saat ini penduduk Kota Batam sudah mencapai 1.236.399 juta jiwa (BPS Kepri, 2017). Semakin meningkatnya jumlah penduduk di Kota Batam berpengaruh terhadap kualitas lingkungan, seperti sampah, sanitasi dan drainase yang buruk, serta. Hal inilah yang menyebabkan sering terjadinya banjir di Kota Batam.

Kavling Mandiri RW 12 merupakan wilayah yang berada di Kelurahan Sei Pelunggut yang sering mengalami banjir apabila turun hujan. Kondisi wilayah lingkungan yang berada diantara 2 selokan besar menyebabkan lingkungan sering dilanda banjir apabila turun hujan, kurangnya pepohonan di lingkungan ini juga menjadi salah satu penyebab banjir karena kurangnya daya serap. Selain itu, peran serta masyarakat rendah disebabkan oleh kurangnya perhatian masyarakat terhadap lingkungan. Kesibukan warga RW 12 dalam memenuhi kebutuhan hidup mempengaruhi rendahnya peran serta masyarakat. Mayoritas masyarakat RW 12 berpendidikan SLTA bahkan sudah banyak warga yang mengeyam pendidikan sarjana. Rata - rata warga di RW 12 memiliki pekerjaan atau usaha yang bisa memenuhi kehidupan seharihari. Namun, kesadaran untuk menjaga lingkungan masih rendah.

Berangkat dari permasalahan diatas, maka perlu dilakukan pengabdian masyarakat yaitu pemberdayaan masyarakat RW 12 dalam kegiatan penghijauan lingkungan di Kavling Mandiri. Penghijauan sangat bermanfaat guna menggulangi berbagai penurunan kualitas lingkungan dengan menggunakan materi pokoknya adalah penggunaan tanaman yang sangat berfungsi dalam biotis tata lingkungan. Tujuan dari pengabdian ini meningkatkan kesadaran masyarakat RW 12 mengenai pentingnya melakukan kegiatan penghijauan lingkungan guna menjaga kualitas lingkungan dan perindangan di lingkungan RW 12. 


\section{METODOLOGI}

\section{Khalayak Sasaran}

Kegiatan pemberdayaan pada masyarakat ini bertujuan untuk melakukan kegiatan penghijauan melalui penanama pohon guna meningkatkan kualita lingkungan, selain itu, kegiatan ini juga bertujuan meningkatkan kesadaran masyarakat mengenai pelestarian lingkungan. Berkaitan dengan hal tersebut, maka khalayak sasaran dari kegiatan ini adalah masyarakat RW 12. Masyarakat RW 12 ini terbagi dalam 3 RT, yaitu RT 01, RT 02, dan RT 03. Jumlah Kepala Keluarga (KK) di RT 01 berjumlah 65 KK, RT 02 berjumlah 61 KK, dan RT 03 berjumlah 57 KK. Tetapi, tidak semua KK terlibat dalam kegiatan penghijauan ini. Ada beberapa KK mewakili dari setiap RT. Mahasiswa juga dilibatkan dalam kegiatan ini sebanyak 26 mahasiswa.

\section{Metode Kegiatan}

Adapun metode kegiatan yang digunakan dalam kegiatan ini adalah :

\section{Pendekatan Persuasif}

Pendekatan ini menitikberatkan kepada ide, sikap, dan usaha-usaha masyarakat atas dasar perubah kontak terarah dan selektif yang datangnya dari pihak luar sehingga menimbulkan motivasi, kreasi dan inovasi bagi masyarakat untuk mampu berfikir dan berbuat sesuai dengan kebenaran.

Pendekatan persuasif yang dilakukan terhadap masyarakat RW 12 Sungai Pelunggut RT 1, 2 dan 3 diawali dengan pertemuan pertama dengan warga melalui komunikasi terbuka dengan tokoh tokoh masyarakat yang cukup berpengaruh dilingkungan, dikesempatan ini Warga memberikan gambaran budaya dan kebiasaan warga RW 12 kemudian menyaring dan mencoba mengeluarkan ide program untuk memberdayakan lingkungan di RW 12, selain itu juga memberikan masukan dan saran apa-apa saja yang harus dibenahi dilingkungan RW 12 .

2. Pendekatan Empirik, Normatik dan Edukatif Yaitu kepedulian terhadap norma-norma yang berlaku baik norma tersirat maupun tersurat di masyarakat.

Pendekatan Empirik dilakukan dengan peninjauan terhadap kebiasaan masyarakat langsung kelapangan dan juga memulai membuka komunikasi terhadap warga dengan membuka sesi 
tanya jawab sehingga mengetahui secara langsung masalah yang terjadi dimasyarakat Kavling Mandiri RW12 Sungai Pelunggut Kecamatan Sagulung yaitu mengenai banjir.

Pendekatan Normatik yang dilakukan dengan memberikan penjelasan kepada masyarakat RW 12 mengenai solusi dari permasalahan dalam menanggulangi banjir adalah melakukan kegiatan penghijauan lingkungan di wilayah tersebut..

Pendekatan Edukatif yang dilakukan yaitu memberikan pengetahuan dan pemahaman kepada masyarakat RW 12 mengenai besarnya manfaat kegiatan penghijauan dalam menjaga kualitas lingkungan terutama banjir guna meningkatkan daya serap di wilayah tersebut.

3. Pendekatan Andragogi

Yaitu sistem pembelajaran dengan prinsip partisipasi dan seni untuk membantu masyarakat belajar dan membelajarkan.

Pendekatan ini membantu untuk meningkatkan peran serta masyarakat dalam kegiatan penghijauan lingkungan di wilayah tersebut. Pendekatan ini juga dpaat meningkatkan kesadaran masyarakat terhadap lingkungan.

\section{Jenis Luaran}

Kegiatan penghijauan lingkungan yang dilakukan di lingkungan RW 12 berharap permasalahan mengenai menurunnya kualitas lingkungan di perkotaan dapat diatasi dengan melibatkan partisipasi masyarakat. Inilah esensi dari pemberdayaan masyarakat. Melalui kegiatan Pengabdian Pada Masyarakat, ada dua luaran yang diharapkan agar dapat tercapai, yaitu:

1. Kegiatan penghijauan lingkungan melalui penanaman pohon dapat menanggulangi berbagai penurunan kualitas lingkungan.

2. Kegiatan penanaman pohon di lingkungan RW 12 dapat meningkatkan daya serap air sehingga dapat mencegah terjadinya banjir di wilayah tersebut.

3. Menumbukan kesadaran kepada masyarakat khususnya masyarakat RW 12 mengenai pentingnya melestarikan dan menjaga lingkungan. 


\section{PEMBAHASAN}

Kegiatan pengabdian masyarakat melalui program pemberdayaan masyarakat RW 12 dalam kegiatan penghijauan lingkungan di Kavling mandiri Kelurahan Sei Pelunggut ini memberikan pendekatan dan penawaran kepada masyarakat RW untuk menyelesaikan permasalahan di RW 12 yang meliputi RT 01, RT 02, dan RT 03. Solusi yang berikan adalah melakukan kegiatan penghijauan di RW 12 dalam menjaga kualitas lingkungan dengan melakukan penanaman pohon yang bertujuan untuk daya serap air serta perindangan. Kegiatan pengabdian ini dilakukan 2 hari, yaitu tanggal 19 - 20 Agustus 2017.

\section{Pelaksanaan Kegiatan Pengabdian Pada Masyarakat}

Kegiatan persiapan meliputi koordinasi dengan pihaj-pihak terkait, persiapan bahan, dan persiapan waktu pelaksanaan. Adapun kegiatan persiapan yang dilakukan antara lain sebagai berikut:

1. Melakukan koordinasi Tim Pengabdian Pada Masyarakat (PPM). Kegiatan rapat kordinasi tim dilakukan pada tanggal 06 Agustus 2017. Rapat dihadiri oleh seluruh anggota tim dan perangkat RW 12. Rapat ini bertujuan untuk menyepakati mengenai waktu dan tempat pelaksanaan kegiatan serta hal-hal lain.

2. Mengadakan pertemuan dengan perangkat RW dan RT serta masyarakat setempat guna membahas kegiatan penghijauan lingkungan, serta memberikan pengetahuan dan pemahaman mengenai pentingnya menjaga lingkungan serta manfaat dari penanaman pohon. Perteman ini sudah dilakukan seminggu sebelumnya.

3. Melakukan observasi di lingkungan RW 12 guna menentukan titik lokasi penanaman pohon.

4. Bersama dengan masyarakat RW 12 menentukan jenis tanaman yang sesuai dengan kondisi lahan

5. Persiapan bahan dan alat. Persiapan pokok pohon yang akan ditanam di wilayah RW 12 dan alat-alat yang akan digunakan untuk penanaman pohon.

6. Persiapan administrasi, meliputi pembuatan izin pelaksanaan ke instansi pemerintah terkait. Dipersiapan juga pembuatan spanduk dan daftar hadir tim PPM. 


\section{Hasil Kegiatan Pengabdian}

Kegiatan penghijauan lingkungan dengan penanaman pohon diikuti oleh masyarakat RW 12, baik Bapak-bapak, Ibu-ibu maupun remaja antusias ikut dalam kegiatan penanaman pohon tersebut, khusunya para ibu mengharapkan kegiatan penghijauan lingkungan menjadi program berkelanjutan yang tidak hanya selesai sampai pada kegaiatan penanaman pohon saja. Karena di wilayah RW 12 Kavling Mandiri ini belum pernah tersentuh kegiatan pengabdian pada masyarakat. Ada sebanyak 22 pokok pohon yang ditanami di sepanjang jalan utama wilayah RW 12.

Setelah kegiatan penanaman pohon selesai dilakukan, selanjutnya dilakukan kegiatan gotong royong untuk membersihan selokan sepanjang kavling mandiri RW 12 yang dilakukan bersama-sama oleh masyarakat RW 12. Dalam kegiatan tersebut juga mengumpulkan tanah humus sisa-sia dari pembakaran sampah, menyisihkan sampah plastik dan organik, mengubur sampah organik dan membakar sampah plastik.

Pelaksanaan kegiatan penghijauan lingkungan melalui penanaman pohon disertai gotong royong memberikan manfaat yang besar bagi lingkungan di RW 12, dimana setelah kegiatan tersebut selesai dilakukan lingkungan RW 12 terlihat lebih rapi dan bersih dan juga dapat meningkatkan daya serap air untuk mencegah terjadinya banjir di wilayah tersebut.

\section{KESIMPULAN}

Dari kegiatan pengabdian yang telah dilaksanakan, maka dapat disimpulkan bahwa:

1. Melalui pendekatan persuasif dapat meningkatkan peran serta masyarakat RW 12 dalam kegiatan penghijauan lingkungan. Terlihat dari tingginya partisipasi masyarakat mulai dari kalangan tua sampai kalangan muda ikut dalam kegiatan penanaman pohon dan gotong royong.

2. Kegiatan penghijauan lingkungan melalui penanaman pohon dapat meningkatkan kualitas lingkungan di RW 12 dan meningkatkan daya serap air guna mencegah terjadinya banjir, serta membuat lingkungan RW 12 menjadi asri dan rindang.

3. Masyarakat dapat berperilaku bersih dengan tidak membuang sampah sembarangan, sehingga lingkungan menjadi rapi dan bersih 


\section{REFERENSI}

Badan Pusat Statistik Kepulauan Riau. 2017. Jumlah penduduk Kota Batam.

Bukit, Herawati. 2010. Penghijauan Kota Sebagai Penunjang Kelestarian Alam di Masa Datang. Jurnal Pengabdian Masyarakat Vol. 16 No. 60 Thn. XVI Juni 2010.

Inoguchi, Takashi. 2003. Kota dan Lingkungan: Pendekatan Baru Masyarakat Berwawaan Ekologis, Jakarta: LP3ES

Lailia, Anita Nur. 2014. Gerakan Masyarakat Dalam Pelestarian Lingkungan Hidup (Studi Tentang Upaya Menciptakan Kampung Hijau Di Kelurahan Gundih Surabaya). Jurnal Politik Muda: Vol. 3 No. 3 Agustus - Desember 2014. 